\title{
A scale development study-I: Ölçek geliştirme çalışması-I: Students' opinions for use of Fizik eğitiminde teknoloji technology in physics education kullanımına yönelik öğrenci
görüşleri $^{1}$
}

\author{
Aytekin Erdem ${ }^{2}$ \\ Gürcan $\mathrm{Uzal}^{3}$
}

\begin{abstract}
Technology which penetrates into our daily lives is also an irreplaceable part of education system. Therefore, technology should be used in physics lessons to make the lesson more interesting and learnable. To achieve this goal, it is important to be determined the opinions of students for use of technology and in which levels they use the opportunitiesin physics lessons. The aim of this study is to develop a Likert-type scale to determine "High School Students' Opinions for Use of Technology in Physics Lessons". Thirty one item draft of scale prepared as a result of literature scanning was broached to six experts who were working in physics teaching. The evaluation of experts finalized the draft scale with 18-item. The study group consisted of 562 students who were chosen by random sampling, were studying at $9^{\text {th }}, 10^{\text {th }}, 11^{\text {th }}$ and $12^{\text {th }}$ grades of nine different high schools (eight of them were public and one was private schools) in Tekirdağ city, Süleymanpaşa district in 2013-2014 academic year. Explanatory and confirmatory factor analyses were conducted for determining the structural validity of scale. As the result of explanatory factor analysis, it was specifies that
\end{abstract}

\section{Özet}

Yaşamımızın her noktasına giren teknoloji, eğitim sisteminin de vazgeçilmez bir parçası durumundadir. $\mathrm{Bu}$ nedenle, fizik derslerini teknolojinin desteği ile daha çekici ve ögrrenilebilir düzeye taşımak ve bazı teknolojik olanaklardan yararlanmak gerekmektedir.Bu amaca erişebilmek için, öğrencilerin fizik derslerinde teknoloji kullanımına yönelik görüşlerinin ve olanakları ne düzeyde kullandıklarının belirlenmesi önemlidir. Bu doğrultuda çalışmanın amacı, lise öğrencilerinin "Fizik Eğitiminde Teknoloji Kullanımına Yönelik Öğrenci Görüşleri”ni belirlemek için Likert tipinde bir ölçeğin geliştirilmesidir.Alan yazın taraması sonucunda oluşturulan 31 maddelik taslak ölçme aracı fizik eğitimi alanında çalışan altı uzmanın görüşüyle değerlendirilmiştir. Bu görüşler doğrultusunda ölçeğin 18 maddeden oluşmasina karar verilmiştir. Araştırmanın örneklemini, 2013-2014 eğitim-öğretim yılında Tekirdağ ili Süleymanpaşa ilçesinde bulunan dokuz (sekizi devlet ve bir özel) lisedeki 9.,10.,11. ve 12. sinıflarda okuyan ve seçkisiz örnekleme yöntemi kullanılarak belirlenen 562 öğrenci oluşturmaktadır. Ölçeğin yap1 geçerliğinin belirlenmesi için faktör

\footnotetext{
${ }^{1} \mathrm{Bu}$ çalışma, 5.Uluslararası Eğitimde Araştırmalar Kongresi (ICRE-2015)'nde sözlü bildiri olarak sunulmuştur (8-10 Ekim 2015, Trakya Üniversitesi, Edirne-Türkiye).

2 Yrd. Doç. Dr., Namık Kemal Üniversitesi, Teknik Bilimler Meslek Yüksekokulu, Elektronik ve Otomasyon Bölümü, aerdem@,nku.edu.tr

${ }^{3}$ Yrd. Doç. Dr., Namik Kemal Üniversitesi, Teknik Bilimler Meslek Yüksekokulu, Elektronik ve Otomasyon Bölümü, guzal@,nku.edu.tr
} 
Erdem, A., \& Uzal, G. (2018). Ölçek geliştirme çalışması-I: Fizik eğitiminde teknoloji kullanımına yönelik öğrenci görüşleri. Journal of Human Sciences, 15(1), 509-526. doi:10.14687/jhs.v15i1.4504

the scale had two sub-dimensions and Likert type fourteen-item. Factor load of items in the scale ranged between 0.482 and 0.820 . As the result of confirmatory factor analysis, fit indices were calculated as $\mathrm{GFI}=0.95$, AGFI $=0.93$, $\mathrm{NFI}=0.97, \mathrm{NFI}=0.98, \mathrm{CFI}=0.98, \mathrm{RMSEA}=0.06$. The obtained values showed that scale items were compatible. In addition, for determining the internal consistency of the scale, Cronbach Alpha co-efficient was calculated as 0.86 for the first sub-dimension, 0.78 for the second subdimension and 0.89 for the whole scale. The findings presented that the prepared scale is a relevant and valid tool to measure the high school students' opinions for use of technology in physics education. It is suggested that the developed scale can also be used in Chemistry and Biology education.

Keywords: Technology; physics; opinions of students; validity; reliability.

(Extended English summary is at the end of this document) analizleri yapılmıştır. Açımlayıcı faktör analizi sonucunda ölçeğin; iki alt boyutlu beşli Likert tipinde 14 maddeden oluştuğu belirlenmiştir. Ölçekte yer alan maddelerin faktör yükleri 0.482 ile 0.820 arasında değişmektedir. Yapılan doğrulayıc1 faktör analizi sonucunda uyum indeksleri $\mathrm{GFI}=0.95, \mathrm{AGFI}=0.93, \mathrm{NFI}=0.97$, $\mathrm{NNFI}=0.98, \quad \mathrm{CFI}=0.98, \mathrm{RMSEA}=0.06$ olarak bulunmuştur. Elde edilen değerler, ölçek maddelerinin iyi bir uyuma sahip olduğunu göstermektedir. Ayrıca ölçeğin iç tutarlılığını belirlemek için Cronbach Alpha katsayıları hesaplanmış olup; birinci alt boyut için 0.86, ikinci alt boyut için 0.78 ve tüm ölçek için 0.89 olarak bulunmuştur. Bu çalışmadan elde edilen bulgular doğrultusunda hazırlanan ölçeğin; lise ögrencilerinin fizik eğitiminde teknoloji kullanımına yönelik görüşlerinin saptanmasında kullanılabilmek üzere geçerli ve güvenilir bir araç olduğu anlaşılmaktadır. Geliştirilen ölçeğin, aynı zamanda Kimya ve Biyoloji eğitiminde de kullanılabileceği önerilmektedir.

Anahtar Kelimeler: Teknoloji; fizik; öğrenci görüşleri; geçerlik; güvenirlik.

\section{Giriş}

Günümüzde bilim ve teknolojideki hızlı değişimler ve gelişmeler, gelecekte bilim ve teknolojide iyi bir yer edinmek isteyen ülkeler için çeşitli olanaklar ve firsatlar sağlamaktadır. Bilim ve teknolojinin gücünü farkeden bazı ülkeler, gelişen teknolojiye uyum sağlayabilecek şekilde gerekli tedbirlerini alarak, sistemlerini güncelleștirmekte ve sorgulamaktadırlar (Bilişim Şurası, 2003; akt., Koç ve Böyük, 2013). Bilgi ve iletişim (bilişim) teknolojilerindeki gelişmeler de, yaşamımızın neredeyse her bölümünü etkilerken günlük yaşantımızın ve iş dünyasının ayrılmaz bir parçası durumundadır. Bu bağlamda teknolojik uygulamaların kullanışllığ1 ve olumlu sonuçları birçok alanda ortaya çıktığı gibi, eğitim alanında da önemli bir yere gelmiştir (Özarslan, Çetin ve Sarıtaş, 2013). Bilgi ekonomisi ve küresel rekabetin gelişimi, hükümetleri öncelikle eğitim niteliği (kalitesi), yaşam boyu öğrenme ve tüm eğitim firsatlarının kararını vermeye zorlamaktadır (UNESCO, 2014).

Çağımızdaki eğitim sisteminde gelecekte ihtiyaç duyulan nitelikli insanların yetiştirilmesi, teknolojinin eğitimle bütünleştirilmesi ve etkili kullanılması oldukça önemlidir. Bu nedenle, bireylerin teknolojik gelişmeleri izleyerek günlük yaşamlarında teknolojiyi etkili bir şekilde kullanabilmeleri için teknoloji okuryazarı olarak yetiştirilmeleri gerekmektedir (Çepni, 2005). Eğitimleri sırasında teknolojiyi ve bilgisayarı öğrenme sürecine daha fazla katabilen bireylerin özgüvenlerinin ve özyeterliklerinin daha fazla olduğu bilinmektedir (Rugayah, Hashim \& Wan, 2004). Bu bağlamda teknoloji destekli fen bilimleri/fizik eğitimi konusundaki çalşmaların; fen konularını öğrenmeyi kolaylaştırdığı, öğretmen ve öğrencilere öğretim/öğrenme sürecinde çeşitli kolaylıklar sağladı̆̆ı, öğrenciyi öğrenci odaklı ve sorgulayıc1 öğrenmeye yönlendirdiği bilinmektedir (Goldworthy, 2000; Jimoyiannis, Komis, 2001; akt., Koç ve Böyük, 2013; Öğüt, Altun, Sulak ve Koçer, 2004). Balcı ve Eşme (2001); teknolojinin yaratıcı düşünme becerilerini 
Erdem, A., \& Uzal, G. (2018). Ölçek geliştirme çalışması-I: Fizik eğitiminde teknoloji kullanımına yönelik öğrenci görüşleri. Journal of Human Sciences, 15(1), 509-526. doi:10.14687/jhs.v15i1.4504

arttırması, öğrenmeyi zaman ve mekândan bağımsız olarak sağlaması nedeniyle, eğitim-öğretim sürecinde kullanılması gerektiğini belirtmişlerdir

Pek çok öğrenci fizik dersinin zor olduğunu düşünür ve söyler (Ornek, Robinson \& Haugan, 2008). Angell ve arkadaşları (2004), lise öğrencileri ve öğretmenlerinin fizik dersi hakkındaki görüşlerini tespit etmeye yönelik yaptıkları araştırma sonucunda; öğrencilerin deneyler, formüller, hesaplamalar, grafikler ve aynı zamanda kavramsal açıklamalar vb. birçok farklı gösterimlerle baş etmek zorunda kalmaları nedeniyle, fizik dersini zor olarak nitelendirdiklerini tespit etmişlerdir (Ornek et al., 2008). Fizik aynı zamanda, özelden genele ve tersine gitme ve geometri ve cebir kullanma yeteneğini zorunlu kıldığı için, pek çok öğrencinin fizik öğrenmesi zorlaşmaktadır (Ornek et al., 2008; Redish, 1994).

Fizik derslerinde kavramsal öğrenme gerçekleşmeden yani ilke ve yasaların içeriği kavranmadan yasaların sonucu olan formülasyon ile işlemlerin yapılması, bu dersin yalnızca matematiksel olarak algilanmasına neden olduğu için, fizik dersi anlaşılması zor bir ders olarak görülmektedir (Kolçak, Moğol ve Ünsal, 2014). Oysa yapılan araştırmalar (Clement, 1982; Halloun \& Hestenes, 1985), fizik öğretiminin zorluğunun yalnızca öğretmen ve öğrencilerden kaynaklanmadığını göstermektedir. Fizik öğretiminde gerekli öğretim yöntemlerinin kullanılamamasının ve öğretime destek olacak yeterli teknolojinin sağlanamamasının fizik öğretimini etkin kılamadığı anlaşılmaktadır. Ayrıca birçok öğretmen de fizik dersini, kavramsal boyutunu dikkate almadan doğrudan doğruya formüllerle anlatmaktadır. Bu nedenle öğrenciler de dersin kavramlarını öğrenme yerine, formülleri ezberlemeye yönelmektedirler. Bunun sonucunda fizik kavramları ve olayları ögrencilerin zihinlerinde kavram yanılgılarına neden olmaktadır. Oysa fizik dersindeki birçok konu görsel olarak açıklanabileceği için, fizik yasalarını ve kavramlarını görsel hale getirerek, öğrencilerin anlamlı öğrenmelerini sağlayabilmek oldukça kolaydır (Kolçak ve ark., 2014).

Geleneksel öğretim yöntemlerinin çoğunun fizik kavramlarını öğretmede yetersiz kaldığ1 görülmektedir (Hestenes \& Halloun, 1987; Heuvelen, 1991; McDermott \&Redish, 1999). Fizik eğitiminde öğrencilerin karşılaştığı anlaşılması zor olan bilgiler, birçok teknoloji desteği ile basitleştirilerek, öğrencilerin öğrenci merkezli öğrenmelerine olanak sağlayabilir (Ramsden, 2002). Öğrencilerin fizik olaylarını tam öğrenebilmeleri için, hazır ya da hazırlanacak teknolojik materyallerin öğrenme sürecinde kullanılmasının öğrenci başarılarını arttırdığı belirtilmektedir (Harwood \& McMahon, 1997; Kolçak ve ark., 2014). Bilgisayar, benzetişim (simülasyon) ve canlandırmanın (animasyon) laboratuvarlarda kullanıldığı bazı çalışmalarda; kullanılan bu yöntemlerin öğrencilerin kavram öğretiminde birçok yöntemden daha verimli olduğu belirlenmiştir (Bozkurt ve Sarıkoç, 2008; Kıyıcı ve Yumuşak, 2005; Özdener, 2002; Şengel, Özden ve Geban, 2002; Yang \& Heh, 2007).

Alan yazında derslerde teknoloji kullanımına yönelik tutum ölçekleri geliştirme ve uygulamaları ile ilgili olarak çeşitli öğrenim kademelerinde araştırmalara rastlanmasına karşın, fizik eğitiminde teknoloji kullanımına yönelik öğrenci tutum ve görüşlerini içeren geliştirilmiş ölçek araştırmaları bulunamamıştır. Bu nedenle çalışmamız önem kazanmaktadır. Eğitimi iyileştirme, niteliği ve verimliliği artırma ile ilgili olarak öğrenci yetkinliklerinin geliştirilmesi, öğretim ortamının yeniden düzenlenerek zenginleştirilmesi, okullarda gözlemlenen öncelikli eğitim sorunları arasında yer almaktadır. Özellikle teknoloji kullanımı ile ilgili bilgi, beceri ve tekniklerin seçilmesi, sürekli eğitim yaklaşımı ile öğrencileri gelişen teknolojiden haberdar ederek ve bilgilendirerek onlara yeni beceriler kazandırmak eğitim paydaşlarının görevi olmalıdır.

Bazı gelişmiş ülkelerde fizik öğretimi programlarında bilgisayar etkileşimli yazılımlar, çoklu ortamlar, internet ve ileri HeMa (hesap makinesi)'nin (G/CAS calculators) vb. daha etkin kullanıldıkları gözlemlenmektedir. Öğrencilerin fizik derslerinde teknolojiyi verimli bir şekilde kullanarak daha nitelikli fizik öğrenebilmeleri için öncelikle teknolojiyi fizik derslerinde kullanma konusunda olumlu görüşlere sahip olmaları gerekmektedir. Son yıllarda Milli Eğitim Bakanlığ1 tarafından liselere Mobil Bilim Laboratuarı, Tablet PC, etkileşimli tahta vb. teknik donanımlar sağlanmış olup, bunların etkin kullanılması gerekir. Bu nedenle, öğrencilerin fizik derslerinde 
Erdem, A., \& Uzal, G. (2018). Ölçek geliştirme çalışması-I: Fizik eğitiminde teknoloji kullanımına yönelik öğrenci görüşleri. Journal of Human Sciences, 15(1), 509-526. doi:10.14687/jhs.v15i1.4504

teknoloji kullanımı konusundaki görüşlerinin bilinmesi fizik derslerinin daha verimli işlenmesi açısından önem kazanmaktadır. Lise öğrencilerinin fizik derslerinde teknoloji kullanımı konusundaki görüşlerinin belirlenmesi için bir ölçeğin geliştirilmesi araştırmamızın temelini oluşturmaktadır.

Türk öğrencilerin karşılaştırmalı uluslararası eğitim araştırmalarında belirlenen durumu, okullarımızdaki matematik ve fen bilimleri eğitiminde nitelik yönünden başarısızlı̆̆ın bir belgesidir (EARGED, 2005, 2007; OECD, 2005). Okullarımızda fizik eğitiminin başarılı olabilmesinin koşullarından biri de, teknoloji desteği ile kavramsal öğretimin gerçekleştirilerek öğrencilerin fizik bilgilerini hızlı bir şekilde yapılandırmalarına olanak sağlanmasıdır. Bunu sağlayabilmek için de öğrencilerin fizik eğitiminde teknoloji kullanılmasına yönelik görüşlerinin belirlenmesi gerekmektedir. $\mathrm{Bu}$ nedenle gerçekleştirilecek araştırmanın amacı; lise öğrencilerinin fizik derslerinde teknoloji kullanımı konusundaki görüşlerinin araştırılmasına yönelik ölçek geliştirilmesidir.

\section{Yöntem}

Fizik derslerinde teknoloji kullanımı konusundaki öğrenci görüşleri ölçeği şu aşamalardan geçilerek hazırlanmıştır.

\section{Madde Havuzunun Oluşturulmas1}

Araştırmacılar tarafindan ilgili alan yazın taraması yapılarak, önceden geliştirilenbazı ölçme araçları gözden geçirilmiştir. Söz konusu incelemelerden (Aydın ve Kara, 2013; Boser, Palmer \& Daugherty, 1998; Edmunds, Thorpe \& Conole, 2012; Francis \& Evans, 1995; Inoue, 2007; Krzilc1k, Temiz, Tan ve İngeç, 2007; Li, 2007; Nuhoğlu, 2008; Öksüz, Ak ve Uça, 2009; Prinsen, Vloman \& Terwel, 2007; Sünkür, Arabacı ve Şanl1, 2012; Tataroğlu ve Erduran, 2010; Tubaishat, 2014; Türel, 2011; Yavuz, 2005; Yurdugül ve Aşkar, 2008) yararlanılmış ve öğrencilerin görüşüne başvurularak deneme amaçlı görüş maddeleri yazılmıştır. Daha sonra seçilen maddelerle ilgili olarak; anlaşılırlık, yeterlik ve uzunluk dereceleri konusunda toplam altı alan uzmanının görüşü alınmıştır. Başlangıçta madde havuzunda 31 adet görüş (ifade) bulunmaktadır.

\section{Kapsam ve Geçerlilik}

Madde havuzunda bulunan 31 adet teknolojinin fizik eğitiminde kullanılması ifadelerinin, kapsam geçerliliği bir form aracılı̆̆1 ile uzmanların görüşüne sunulmuş olup yapılan öneriler doğrultusunda madde havuzunda gerekli düzenlemeler gerçekleştirilmiştir.

Kapsam geçerlik oranları, her bir madde için olumlu (ölçer) yanıt vermiş olan uzman sayılarının toplamının, toplam uzman sayısının yarısına oranının bir eksiği olarak ifade edilir.

$$
\text { KGO }=\frac{\text { NG }}{\mathrm{N} / 2}-1 \text { Burada; KGO, Kapsam Geçerlik Oranı; }
$$

NG, ölçer diyen uzman sayısı; N, toplam uzman sayısıdır.

Her bir madde için elde edilen KGO'larından, istatistiksel olarak anlamsız bulunan 13 madde (M05, M06, M08, M10, M13, M15, M20, M24, M25, M27, M28, M29, M31) formdan çıkarılmıştır (Tablo 1). Altı uzman görüşü için aday ölçek formunun Kapsam Geçerlilik Ölçütü (KGÖ) 0.99'dır (Yurdugül, 2005). Formda kalan KGO’larının ortalaması alınarak Kapsam Geçerlilik İndeksi (KGI) 1.00 olarak bulunmuştur. KGİ>=KGÖ olduğu için oluşturulan tüm ölçeğin kapsam geçerliliği istatistiksel olarak anlamlıdır. 
Erdem, A., \& Uzal, G. (2018). Ölçek geliştirme çalışması-I: Fizik eğitiminde teknoloji kullanımına yönelik öğrenci görüşleri. Journal of Human Sciences, 15(1), 509-526. doi:10.14687/jhs.v15i1.4504

Tablo 1.Form'daki maddeler için uzman görüşleri ve kapsam geçerlik oranları

\begin{tabular}{|c|c|c|c|c|c|}
\hline \multirow{2}{*}{ M.No } & \multirow{2}{*}{ Öğrenci Görüşleri } & \multicolumn{3}{|c|}{$\begin{array}{l}\text { Madde Hedeflenen } \\
\text { Amaci }\end{array}$} & \multirow{2}{*}{ KGO } \\
\hline & & Ölçer & $\begin{array}{l}\text { Ilişkili/ } \\
\text { gereksiz }\end{array}$ & Ölçmez & \\
\hline & Fizik Derslerinde Teknoloji Kullanımı & & & & \\
\hline M01 & Konu içeriğini kolaylıkla anlamama yardımcı olur & 6 & - & - & $1.00^{+}$ \\
\hline M02 & Konuları kısa sürede öğrenmeme olumlu etkisi vardır & 6 & - & - & $1.00^{+}$ \\
\hline M03 & Bilgiye hızlı erişmemde çeşitli olanaklar sağlar & 6 & - & - & $1.00^{+}$ \\
\hline M04 & Bilgileri kalıcı öğrenmemde yardımcı olur & 6 & - & - & $1.00^{+}$ \\
\hline M05* & Gözlem ve deneme yapmama olanak sağlar & 3 & 1 & 2 & $0.00^{-}$ \\
\hline M06* & Öğretmen ile iletişimimi kolaylaştırır & 5 & 1 & - & $0.67^{-}$ \\
\hline M07 & Birden çok duyu organıma hitap eder & 6 & - & - & $1.00^{+}$ \\
\hline M08* & Arkadaşlarımla etkileşimime yardımcı olur & 4 & - & 2 & $0.33^{-}$ \\
\hline M09 & Öğretimi bireyselleştirmek için uygundur & 6 & - & - & $1.00^{+}$ \\
\hline M10* & Sosyo-psikolojik gelişimimi engeller & 4 & 1 & 1 & $0.33^{-}$ \\
\hline M11 & Konuyu kendi öğrenme hızıma göre öğrenmemde yardımcı olur & 6 & - & - & $1.00^{+}$ \\
\hline M12 & Teknoloji kullanımında özgüvenim vardır & 6 & - & - & $1.00^{+}$ \\
\hline M13* & Üst düzey düşünme becerilerimi geliştirir & 5 & - & 1 & $0.67^{-}$ \\
\hline M14 & Laboratuarda yapılamayan deneylerin anlaşılmasına katkısı olur & 6 & - & - & $1.00^{+}$ \\
\hline M15* & Kavram yanılgilarımı gidermede olumlu etkileri vardır & 4 & - & 2 & $0.33^{-}$ \\
\hline M16 & Teknoloji kullanımı öğrenme ortamını zenginleştirir & 6 & - & - & $1.00^{+}$ \\
\hline M17 & Teknoloji kullanımı hayal gücümü geliştirir & 6 & - & - & $1.00^{+}$ \\
\hline M18 & Yaratıcı düşünme becerilerimi geliştirmede yardımcıdır & 6 & - & - & $1.00^{+}$ \\
\hline M19 & Konuları öğrenmede ilgimi arturır & 6 & - & - & $1.00^{+}$ \\
\hline M20* & Teknoloji kullanımı öğrenme hevesimi engeller & 5 & - & 1 & $0.67^{-}$ \\
\hline M21 & Öğrenmeye daha çok güdüler (isteklendirir) & 6 & - & - & $1.00^{+}$ \\
\hline M22 & Teknoloji kullanımı takım çalışması becerilerimi geliştirir & 6 & - & - & $1.00^{+}$ \\
\hline M23 & Bilimsel düşünme becerilerimi geliştirmeme katkısı olur & 6 & - & - & $1.00^{+}$ \\
\hline M24* & Fizik dersine yönelik tutumumu değiştirmez & 4 & - & 2 & $0.33^{-}$ \\
\hline M25* & Fizik dersine yönelik ilgimi azaltır & 5 & - & 1 & $0.67^{-}$ \\
\hline M26 & Öğrenme etkinliklerine katılım olanaklarını artırır & 6 & - & - & $1.00^{+}$ \\
\hline M27* & Fizik dersinde başarıma olumlu bir katkısı yoktur & 5 & - & 1 & $0.67^{-}$ \\
\hline M28* & Konu içeriklerini öğrenmemi zorlaştırır & 5 & - & 1 & $0.67^{-}$ \\
\hline M29* & Fizik dersinde dikkatimin dağılmasina neden olur & 5 & - & 1 & $0.67^{-}$ \\
\hline M30 & Teknolojinin derslerde daha sık kullanılmasını isterim & 6 & - & - & $1.00^{+}$ \\
\hline \multirow[t]{4}{*}{ M31* } & Teknoloji kullanımı sınav endişemi artırır & 4 & 1 & 1 & $0.33^{-}$ \\
\hline & Uzman Sayıs1 & 6 & & & \\
\hline & Kapsam Geçerlik Ölçütü & 0.99 & & & \\
\hline & Kapsam Geçerlik İndeksi & 1.00 & & & \\
\hline
\end{tabular}

*İstatistiksel olarak anlamsız bulunduğu için formdan çıkarılan maddeler.

\section{Aday Formun Yapılandirilması}

Kapsam geçerliliği uzmanlarca sağlanan 18 maddelik aday formu hazırlanmıştır. Ölçekteki maddelere kişilerin katılma dereceleri; aday formundaki olumlu soru maddelerinde 1 "kesinlikle katılmiyorum", 2 "katılmiyorum", 3 "fikrim yok", 4 "katılıyorum", 5 "tamamen katıliyorum", olumsuz soru maddelerinde ise 1 "kesinlikle kat1lyorum", 2 "katıllyorum", 3 "fikrim yok", 4 "katılmıyorum", 5 "kesinlikle katılmıorum" şeklinde sınıflandırılmıştır. Aday formda ayrıca kişilerin demografik özellikleri hakkında bilgi edinmeye yönelik yedi (cinsiyet, yaş, okul türü, sınıf, aile gelir durumu, evde bilgisayar, evde internet bağlantısı)adet soru yer almaktadır.

\section{Aday Form ve Çalışma Grubu}

Önerilen araştırmada uygulamak amacıyla bir aday form tasarlanmış olup, formu geliştirmek ve iyileştirmek üzere pilot çalışması yapılmıştır. Bu çerçevede tasarlanan aday form ve araştırmanın çalışma grubu ile ilgili bilgiler şunlardır: 
Erdem, A., \& Uzal, G. (2018). Ölçek geliştirme çalışması-I: Fizik eğitiminde teknoloji kullanımına yönelik öğrenci görüşleri. Journal of Human Sciences, 15(1), 509-526. doi:10.14687/jhs.v15i1.4504

Aday Form: Bu form, araştırmada yanıtlanacak sorulara ve incelenecek probleme göre tasarlanmıştır. Teknolojinin Fizik Eğitiminde Kullanımına Yönelik Öğrenci Görüş Ölçeği (TFEKYÖGÖ): Aday form (Taslak ölçek), lise öğrencilerinin fizik derslerinde teknoloji kullanımı ile ilgili görüşlerini yansıtan 18 maddeden oluşmaktadır. Ölçme aracından alınabilecek en düşük puan 18 , en yüksek puan ise 90 'dır.

Çalışma Grubu: Araştırmanın çalışma grubu; 2013-2014 eğitim-öğretim yılında, Tekirdağ ili Süleymanpaşa ilçesindeki Ebru Nayim Fen Lisesi, Aka Koleji Fen Lisesi, Tekirdağ Anadolu Lisesi, Tekirdağ Belediyesi Anadolu Öğretmen Lisesi, Namık Kemal Lisesi, Fatih Anadolu Lisesi, Aka Koleji Fen ve Anadolu Lisesi ile Tuğlacılar Anadolu Lisesi’nin 9.,10.,11. ve 12. Sinıflarında öğrenim gören 562 öğrenciden oluşmaktadır.

\section{Bulgular ve Yorumlar}

\section{Güvenirlik Hesaplaması Aşaması}

Araştırma sonucunda elde edilen verilere ilk önce iki aşamalı madde analizi, ardından sırası ile açımlayıcı ve doğrulayıcı faktör analizleri uygulanmıştır. Analizlerde PASW Statistics 18 ve LISREL 9.1 programları kullanılmıştır.

Taslak ölçekteki maddelerin ölçme gücünü saptamak amacı ile genellikle iç tutarlllik ölçütüne dayalı analiz ile korelasyona dayalı analiz olmak üzere iki farklı madde analizi yapılmaktadır (Cansız, Aktaş ve Aktaş, 2013, s:234; akt.; Bindak, 2004). Bu araştırmada alt-üst grup ortalamaları farkına ve korelasyona ilişkin madde analizi gerçekleştirilmiştir.

\section{a)Alt-Üst Grup Ortalamaları Farkına Dayalı Madde Analizi}

Ölçekteki maddelerin ayırt edicilik güçlerinin belirlenebilmesi için, her bir maddeye ait üst grup ve alt grup teknoloji kullanımı puanlarının ortalamaları arasındaki farkın $t$ değeri hesaplanmıştır. Bunun için geliştirilen ölçekten elde edilen ham puanlar standartlaştırılarak eşit aralığa dönüştürülmüştür. $\mathrm{Bu}$ dönüştürmede $\mathrm{T}$ puanı olarak adlandırılan standart puanlar bulunmuş ve puanlar yüksekten düşüğe doğru sıralanmıştır. Alt ve üst gruplar, ölçeğe yanıt veren tüm öğrencilerin \%27'sini oluşturan 152'şer kişiden oluşturulmuştur.

Tablo 2. Ölçeğin Alt \%27 ve Üst \%27’lik Grupların Madde Ortalamaları İçin t-Testi Sonuçları

\begin{tabular}{|c|c|c|c|c|c|c|c|}
\hline Madde No & & $\mathbf{N}$ & $\bar{X}$ & $\mathbf{S}$ & Sd & $\mathbf{t}$ & $\mathrm{p}$ \\
\hline \multirow[t]{2}{*}{$\overline{\mathrm{M} 01}$} & Ust Grup & 152 & 4.49 & 0.69 & \multirow{2}{*}{302} & \multirow{2}{*}{14.796} & \multirow{2}{*}{0.000} \\
\hline & Alt Grup & 152 & 2.91 & 1.12 & & & \\
\hline \multirow[t]{2}{*}{ M02 } & Ust Grup & 152 & 4.40 & 0.69 & \multirow{2}{*}{302} & \multirow{2}{*}{15.946} & \multirow{2}{*}{0.000} \\
\hline & Alt Grup & 152 & 2.75 & 1.07 & & & \\
\hline \multirow[t]{2}{*}{ M03 } & Ust Grup & 152 & 4.61 & 0.69 & \multirow{2}{*}{302} & \multirow{2}{*}{11.741} & \multirow{2}{*}{0.000} \\
\hline & Alt Grup & 152 & 3.25 & 1.25 & & & \\
\hline \multirow[t]{2}{*}{ M04 } & Ust Grup & 152 & 4.42 & 0.58 & \multirow{2}{*}{302} & \multirow{2}{*}{18.717} & \multirow{2}{*}{0.000} \\
\hline & Alt Grup & 152 & 2.60 & 1.05 & & & \\
\hline \multirow[t]{2}{*}{ M07 } & Ust Grup & 152 & 4.52 & 0.65 & \multirow{2}{*}{302} & \multirow{2}{*}{14.248} & \multirow{2}{*}{0.000} \\
\hline & Alt Grup & 152 & 3.03 & 1.11 & & & \\
\hline \multirow[t]{2}{*}{ M09 } & Ust Grup & 152 & 3.68 & 0.97 & \multirow{2}{*}{302} & \multirow{2}{*}{6.098} & \multirow{2}{*}{0.000} \\
\hline & Alt Grup & 152 & 2.96 & 1.11 & & & \\
\hline \multirow[t]{2}{*}{ M11 } & Ust Grup & 152 & 4.17 & 0.87 & \multirow{2}{*}{302} & \multirow{2}{*}{11.960} & \multirow{2}{*}{0.000} \\
\hline & Alt Grup & 152 & 2.84 & 1.06 & & & \\
\hline \multirow[t]{2}{*}{ M12 } & Ust Grup & 152 & 4.27 & 0.89 & \multirow{2}{*}{302} & \multirow{2}{*}{7.773} & \multirow{2}{*}{0.000} \\
\hline & Alt Grup & 152 & 3.35 & 1.15 & & & \\
\hline \multirow[t]{2}{*}{ M14 } & Ust Grup & 152 & 4.39 & 0.91 & \multirow{2}{*}{302} & \multirow{2}{*}{15.067} & \multirow{2}{*}{0.000} \\
\hline & Alt Grup & 152 & 2.51 & 1.24 & & & \\
\hline
\end{tabular}


Erdem, A., \& Uzal, G. (2018). Ölçek geliştirme çalışması-I: Fizik eğitiminde teknoloji kullanımına yönelik öğrenci görüşleri. Journal of Human Sciences, 15(1), 509-526. doi:10.14687/jhs.v15i1.4504

Tablo 2'nin devam1

\begin{tabular}{llllllll}
\hline Madde No & & $\mathbf{N}$ & $\overline{\mathrm{X}}$ & $\mathbf{S}$ & Sd & $\mathbf{t}$ & $\mathbf{p}$ \\
\hline M16 & Ust Grup & 152 & 4.52 & 0.69 & 302 & 13.145 & $\mathbf{0 . 0 0 0}$ \\
& Alt Grup & 152 & 3.18 & 1.05 & & & \\
M17 & Ust Grup & 152 & 4.61 & 0.59 & 302 & 19.304 & $\mathbf{0 . 0 0 0}$ \\
& Alt Grup & 152 & 2.70 & 1.07 & & & \\
M18 & Ust Grup & 152 & 4.37 & 0.70 & 302 & 16.724 & $\mathbf{0 . 0 0 0}$ \\
& Alt Grup & 152 & 2.73 & 0.98 & & & \\
M19 & Ust Grup & 152 & 4.45 & 0.71 & 302 & 17.569 & $\mathbf{0 . 0 0 0}$ \\
& Alt Grup & 152 & 2.59 & 1.09 & & & \\
M21 & Ust Grup & 152 & 4.45 & 0.74 & 302 & 20.370 & $\mathbf{0 . 0 0 0}$ \\
M22 & Alt Grup & 152 & 2.41 & 0.99 & & & \\
& Ust Grup & 152 & 4.00 & 0.97 & 302 & 14.515 & $\mathbf{0 . 0 0 0}$ \\
M23 & Alt Grup & 152 & 2.36 & 1.00 & & & \\
& Ust Grup & 152 & 4.25 & 0.96 & 302 & 13.379 & $\mathbf{0 . 0 0 0}$ \\
M26 & Alt Grup & 152 & 2.76 & 0.97 & & & \\
& Ust Grup & 152 & 4.32 & 0.77 & 302 & 16.427 & $\mathbf{0 . 0 0 0}$ \\
M30 & Alt Grup & 152 & 2.67 & 0.97 & & & \\
& Ust Grup & 152 & 4.47 & 0.76 & 302 & 18.175 & $\mathbf{0 . 0 0 0}$ \\
\hline
\end{tabular}

Tablo 2'de tüm t değerlerinin anlamlı olduğu görülmektedir. Bu nedenle, gerçekleştirilen analiz sonucunda ölçekten madde çıkarılmasına gerek görülmemiştir.

\section{b)Madde-Toplam Puan Korelasyonu}

Ölçekteki 18 maddeden hangilerinin çalıştığını belirlemek amacı ile her bir maddenin ayırt ediciliğine, yani madde-toplam korelasyonuna bakılmıştır. Madde-toplam puan korelasyonu, test maddelerinden alınan puanlar ile testin toplam puanı arasındaki ilişkiyi açıklamaktadır. Maddetoplam korelasyonunun pozitif ve yüksek olması, maddelerin benzer davranışları örneklediğini ve ölçme aracının iç tutarlılığının (güvenilirliğinin) yüksek olduğunu gösterir. Madde-toplam korelasyonu katsayıları $\mathrm{r} \geq 0.40$ için çok iyi bir madde, $0.30 \leq \mathrm{r} \leq 0.39$ için iyi derecede bir madde, $0.20 \leq \mathrm{r} \leq 0.29$ için zorunlu görülmesi durumunda veya düzeltildikten sonra teste alınabilecek bir madde, $\mathrm{r} \leq 0.19$ için ise teste alınmaması gereken zayıf bir madde olarak yorumlanabileceği belirtilmektedir (Büyüköztürk, 2012; Kalayc1, 2005). Ayrıca, negatif değerler teste alınmamalıdır. Teknoloji kullanımı ölçeği madde-toplam korelasyonları ile alt \%27 ve üst \%27'lik grupların madde puanlarının karşılaştırılmasına ilişkin t-testi sonuçları Tablo 3'de verilmiştir.

Tablo 3. Madde Analizi Sonuçları

\begin{tabular}{lll}
\hline Madde No & $\begin{array}{l}\text { Madde-Toplam } \\
\text { Korelasyonu }\end{array}$ & $\begin{array}{l}\mathrm{t} \\
(\mathrm{Alt} \% 27-\mathrm{U} s \mathrm{~s} \% 27)^{2}\end{array}$ \\
\hline M01 & 0.582 & $14.796^{* * *}$ \\
M02 & 0.581 & $15.946^{* * *}$ \\
M03 & 0.512 & $11.741^{* * *}$ \\
M04 & 0.672 & $18.717^{* * *}$ \\
M07 & 0.529 & $14.248^{* * *}$ \\
M09 & $\mathbf{0 . 3 1 3}$ & $6.098^{* * *}$ \\
M11 & 0.577 & $11.960^{* * *}$ \\
M12 & $\mathbf{0 . 3 5 9}$ & $\mathbf{7 . 7 7 3}^{* * *}$ \\
M14 & 0.495 & $15.067^{* * *}$ \\
M16 & 0.550 & $13.145^{* * *}$ \\
M17 & 0.584 & $19.304^{* * *}$ \\
M18 & 0.628 & $16.724^{* * *}$ \\
\hline
\end{tabular}


Erdem, A., \& Uzal, G. (2018). Ölçek geliştirme çalışması-I: Fizik eğitiminde teknoloji kullanımına yönelik öğrenci görüşleri. Journal of Human Sciences, 15(1), 509-526. doi:10.14687/jhs.v15i1.4504

Tablo 3'ün devam1

\begin{tabular}{lll}
\hline Madde No & $\begin{array}{l}\text { Madde-Toplam } \\
\text { Korelasyonu }^{1}\end{array}$ & $\begin{array}{l}\mathrm{t} \\
(\text { Alt } \% 27-\text { Üst } \% 27)^{2}\end{array}$ \\
\hline M19 & 0.593 & $17.569^{* * *}$ \\
M21 & 0.669 & $20.370^{* * *}$ \\
M22 & 0.490 & $14.515^{* * *}$ \\
M23 & 0.518 & $13.379^{* * *}$ \\
M26 & 0.582 & $16.427^{* * *}$ \\
M30 & 0.620 & $18.175^{* * *}$ \\
\hline${ }^{1} \mathrm{n}=562$ & ${ }^{2} \mathrm{n}_{1}=\mathrm{n}_{2}=152^{* * *} \mathrm{p}<0.001$
\end{tabular}

Analiz sürecinde, madde toplam korelasyonlarının 0.40 'dan küçük olduğu için, önce M09 sonra M12 nolu maddeler ölçekten çıkarılmıştır. Ölçekte kalan maddelerin tümü için maddetoplam korelasyonlarının 0.490-0.672 arasında değiştiği ve $t$ değerlerinin anlamlı olduğu anlaşılmaktadır (Tablo 3). Buna göre ölçekte bulunan maddelerin çok iyi düzeyde oldukları söylenebilir (Tabachnick \& Fidel, 2001).

\section{Geçerlilik Hesaplaması Aşaması}

Yapı geçerliğini belirlemek için açımlayıcı ve doğrulayıcı faktör analizleri yapılmıştır.

\section{a)Açımlayıcı Faktör Analizi (AFA)}

Açımlayıcı faktör analizinden önce, örneklem büyüklüğünün faktörleştirmeye uygunluğunu test etmek amacıyla Kaiser-Meyer-Olkin (KMO) testi uygulanmıştır. KMO testi sonuçları; 0.500.60 arasında ise örneklem büyüklügünün "kötü", 0.60-0.70 arasında ise örneklem büyüklügünün “zayıf”, 0.70-0.80 arasında ise örneklem büyüklüğünün "orta", 0.80-0.90 arasinda ise örneklem büyüklüğünün "iyi”, 0.90 ve üzerinde ise örneklem büyüklügünün "mükemmel” olduğu yorumu yapılabilir (Leech, Barret ve Morgan, 2005, Akt., Çokluk, Şekercioğlu ve Büyüköztürk, 2012; Şencan, 2005; Tavşancil, 2005).

Tablo 4. Ölçeğin KMO ve Bartlett's Testi Sonuçları

\begin{tabular}{lrr}
\hline Kaiser-Meyer-Olkin Örneklem Ölçüm Değer Yeterliği & 0.939 \\
Bartlett's Testi & Yaklaşık Ki-Kare Değeri & 3339.822 \\
& sd & 120 \\
& p & 0.000 \\
\hline
\end{tabular}

Tablo 4'de, yapılan Kaiser-Meyer-Olkin (KMO) ve Bartlett's Testi Sonuçları görülmektedir. Analiz sonucunda KMO değerinin 0.939 olduğu belirlenmiştir. Bu bulgu doğrultusunda, örneklem büyüklüğ̈ünün faktör analizini yapmak için "mükemmel derecede yeterli" olduğu sonucuna ulaşılmıştır. Ayrıca Bartlett küresellik testi sonuçları incelendiğinde, elde edilen ki-kare değerinin manidar olduğu görülmüştür $\left(\chi_{(120)}^{2}=3339.822 ; \mathrm{p}<0.01\right)$. Bu nedenle, verilerin çok değişkenli normal dağılımdan geldiği kabul edilmiştir.

Tablo 5’te, ölçekte yer alan bir maddenin analizde yer alan maddelerle paylaştığı varyans miktarı olan ortak faktör varyans değerleri verilmiştir. 
Erdem, A., \& Uzal, G. (2018). Ölçek geliştirme çalışması-I: Fizik eğitiminde teknoloji kullanımına yönelik öğrenci görüşleri. Journal of Human Sciences, 15(1), 509-526. doi:10.14687/jhs.v15i1.4504

Tablo 5. Ölçek Maddelerinin Ortak Faktör Varyans Değerleri

\begin{tabular}{lll}
\hline Maddeler & Başlang1ç Değerleri & Ç1kartma Değeri \\
\hline M01 & 1.000 & 0.607 \\
M02 & 1.000 & 0.645 \\
M03 & 1.000 & $\mathbf{0 . 6 6 8}$ \\
M04 & 1.000 & 0.563 \\
M07 & 1.000 & 0.434 \\
M11 & 1.000 & 0.407 \\
M14 & 1.000 & $\mathbf{0 . 3 6 3}$ \\
M16 & 1.000 & 0.408 \\
M17 & 1.000 & 0.479 \\
M18 & 1.000 & 0.547 \\
M19 & 1.000 & 0.513 \\
M21 & 1.000 & 0.608 \\
M22 & 1.000 & 0.508 \\
M23 & 1.000 & 0.409 \\
M26 & 1.000 & 0.481 \\
M30 & 1.000 & 0.497 \\
\hline
\end{tabular}

Çıkartma Yöntemi: Temel Bileşenler Analizi

Maddelerin ortak faktör varyanslarının 1.00'e yakın ya da 0.66'nın üzerinde olması iyi bir çözümdür. Ancak uygulamada bunu karşılamak genellikle zordur. Ortak faktör varyansının yüksek olmasının, modele ilişkin açıklanan toplam varyansı artıracağı dikkate alınmalıdır (Büyüköztürk, 2012). Ölçekteki maddelerin ortak varyans değerleri 0.363 ile 0.668 arasında değişmektedir. Sonuç olarak, maddelerin ortak varyanslarının yüksek olması nedeniyle, bu süreçte ölçekten hiçbir bir maddenin çıkarılmasına gerek görülmemiştir.

Lise öğrencilerinin teknoloji kullanımına yönelik görüşleri ölçeğinin faktör desenini ortaya koymak amacıyla faktörleştirme yöntemi olarak temel bileşenler analizi; döndürme yöntemi olarak da dik döndürme yöntemlerinden maksimum değişkenlik (varimax) tekniği kullanılmıştır. Yapılan analiz sonucunda, analize temel olarak alınan 16 madde için öz değeri bir ( 1 )'in üzerinde olan iki bileşen olduğu görülmüştür. Bu bileşenlerin toplam varyansa yaptıkları katk1 \%49.16'dır.

Söz konusu bu iki bileşen, gerek toplam varyans tablosu ve gerekse yamaç-birikinti grafiği de incelenerek, toplam varyansa yaptıkları katkının önemi çerçevesinde değerlendirildiğinde, birinci bileşenin varyansa önemli bir katk1 yaptı̆̆1 (\%40.97), ikinci bileşenin ise varyansa daha az katk1 (\%8.19) yaptı̆̆1 görülmüştür. Bu çerçevede, analizin iki faktör için tekrarlanmasına karar verilmiştir.

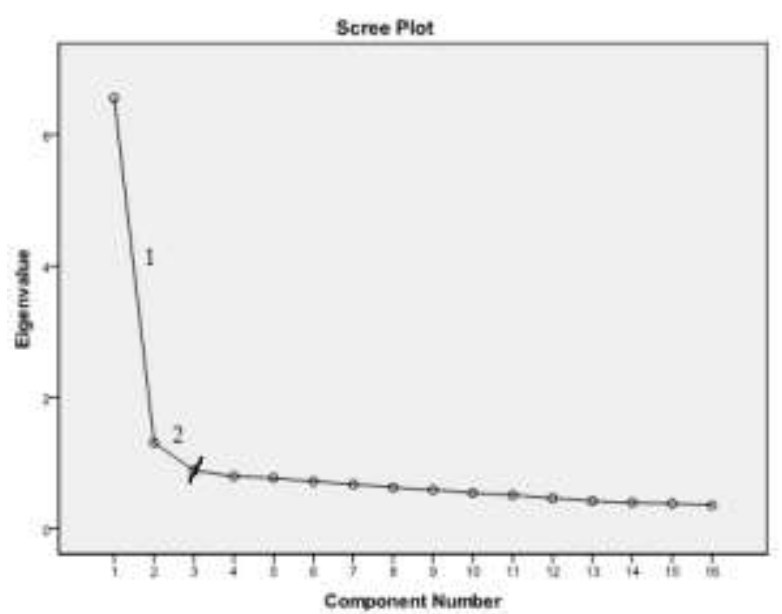

Şekil 1. Yamaç-Birikinti Grafiği 
Erdem, A., \& Uzal, G. (2018). Ölçek geliştirme çalışması-I: Fizik eğitiminde teknoloji kullanımına yönelik öğrenci görüşleri. Journal of Human Sciences, 15(1), 509-526. doi:10.14687/jhs.v15i1.4504

Tablo 6'da, 4.ve 11. maddelerin analiz dışı bırakılması ile son şeklini alan ölçeğin, maddeleri için açılanan toplam varyans değerleri görülmektedir.

Teknoloji kullanımı ölçeğinin faktör desenini ortaya koymak amacıyla yapılan açımlayıcı faktör analizinde faktör yük değerlerinin; a) 0.71 olması halinde (varyansin \%50'sini açılar) “mükemmep', b) 0.63 olması halinde (varyansin \%40'1nı açılar) "çok iyı", c) 0.55 olması halinde (varyansin \%30'unu açıklar) “iyı”, d) 0.45 olması halinde (varyansın \%20'sini aç1klar) "vasat", e) 0.32 olması halinde (varyansın \%10'unu açıklar) "raynf" olarak değerlendirilebileceğini belirtmişlerdir (Comrey\& Lee, 1992, as cited Tabachnick \& Fidel, 2001).

Tablo 6. Ölçeğin Maddeleri İçin Açıklanan Toplam Varyans Değerleri

\begin{tabular}{|c|c|c|c|c|c|c|c|c|c|}
\hline \multirow[b]{2}{*}{ Bileşenler } & \multicolumn{3}{|c|}{ Başlangıç Öz Değerleri } & \multicolumn{2}{|c|}{$\begin{array}{l}\text { Çıkartılmış Kareli } \\
\text { Yüklerin Toplamı }\end{array}$} & & \multicolumn{3}{|c|}{$\begin{array}{l}\text { Döndürülmüş Kareli } \\
\text { Yüklerin Toplamı }\end{array}$} \\
\hline & Toplam & $\begin{array}{l}\text { Varyans } \\
\text { Yüzdesi }\end{array}$ & $\begin{array}{l}\text { Toplanmiş } \\
\text { Yüzde }\end{array}$ & Toplam & $\begin{array}{l}\text { Varyans } \\
\text { Yüzdesi }\end{array}$ & $\begin{array}{l}\text { Toplanmiş } \\
\text { Yüzde }\end{array}$ & Toplam & $\begin{array}{l}\text { Varyans } \\
\text { Yüzdesi }\end{array}$ & $\begin{array}{l}\text { Toplanmış } \\
\text { Yüzde }\end{array}$ \\
\hline 1 & 5.715 & 40.823 & 40.823 & 5.715 & 40.823 & 40.823 & 4.172 & 29.801 & 29.801 \\
\hline 2 & 1.301 & 9.296 & 50.119 & 1.301 & 9.296 & 50.119 & 2.844 & 20.318 & 50.119 \\
\hline 3 & 0.885 & 6.323 & 56.442 & & & & & & \\
\hline 4 & 0.770 & 5.501 & 61.943 & & & & & & \\
\hline 5 & 0.768 & 5.488 & 67.431 & & & & & & \\
\hline 6 & 0.678 & 4.843 & 72.273 & & & & & & \\
\hline 7 & 0.639 & 4.564 & 76.838 & & & & & & \\
\hline 8 & 0.612 & 4.372 & 81.210 & & & & & & \\
\hline 9 & 0.524 & 3.743 & 84.953 & & & & & & \\
\hline 10 & 0.495 & 3.532 & 88.485 & & & & & & \\
\hline 11 & 0.446 & 3.187 & 91.673 & & & & & & \\
\hline 12 & 0.410 & 2.929 & 94.602 & & & & & & \\
\hline 13 & 0.395 & 2.821 & 97.423 & & & & & & \\
\hline 14 & 0.361 & 2.577 & 100.000 & & & & & & \\
\hline
\end{tabular}

Yapılan analizlerde faktör yük değerleri için alt sınır 0.40 olarak belirlenmiştir. İki faktör için yapılan analizde, maddeler, binişiklik ve faktör yük değerlerinin kabul düzeyini karşılayıp karşılamaması açısından değerlendirildiğinde, iki maddenin binişik olduğu (4. ve 11. maddeler) görülmüştür. Bu maddelerin analiz dişında birakılması sonucunda elde edilen faktör deseni, maddelerin faktör yük değerleri ve ortak faktör varyansları Tablo 7'de verilmiştir.

Tablo 7. Teknoloji Kullanımı Ölçeğinin Faktör deseni (Döndürme-Varimax)

\begin{tabular}{|c|c|c|c|}
\hline Maddeler & $\begin{array}{l}\text { Teknolojinin } \\
\text { Önemi, İlgi ve } \\
\text { Ögrrenme } \\
\text { Ortamına } \\
\text { Katkısı }\end{array}$ & $\begin{array}{l}\text { Teknolojinin } \\
\text { Öğrenmeye ve } \\
\text { Bilgiye Erişime } \\
\text { Katkıs1 }\end{array}$ & $\begin{array}{l}\text { Ortak Faktö1 } \\
\text { Varyans1 }\left(h^{2}\right)\end{array}$ \\
\hline$\overline{\mathrm{M} 21}$ & 0.714 & 0.282 & 0.59 \\
\hline M22 & 0.706 & -0.009 & 0.50 \\
\hline M18 & 0.696 & 0.221 & 0.53 \\
\hline M26 & 0.670 & 0.198 & 0.48 \\
\hline M19 & 0.661 & 0.224 & 0.49 \\
\hline M17 & 0.628 & 0.272 & 0.47 \\
\hline M30 & 0.612 & 0.335 & 0.49 \\
\hline M23 & 0.561 & 0.224 & 0.37 \\
\hline M16* & 0.502 & 0.386 & 0.40 \\
\hline M14* & 0.482 & 0.283 & 0.31 \\
\hline M03 & 0.115 & 0.820 & 0.69 \\
\hline M02 & 0.231 & 0.778 & 0.66 \\
\hline M01 & 0.264 & 0.737 & 0.61 \\
\hline M07 & 0.299 & 0.583 & 0.43 \\
\hline
\end{tabular}


Erdem, A., \& Uzal, G. (2018). Ölçek geliştirme çalışması-I: Fizik eğitiminde teknoloji kullanımına yönelik öğrenci görüşleri. Journal of Human Sciences, 15(1), 509-526. doi:10.14687/jhs.v15i1.4504

Tablo 7'den görüldüğü üzere, faktör yük değerleri büyüklük açısından incelendiğinde, iki madde haricinde (M14. ve M16. maddeler) yük değerlerini "iyi”den "mükemmel”e doğru nitelendirmek olanaklıdır. Söz konusu iki maddenin yük değerleri ise "orta" olarak nitelendirilebilir.

İki faktör için tekrarlanan analizde, faktörlerin toplam varyansa yaptıkları katkının a) "Teknolojinin Önemi, İlgi ve Öğrenme Ortamına Katkısı" faktörü için \%40.82, b) "Teknolojinin Öğrenmeye ve Bilgiye Erişime Katkısı” faktörü için \%9.30 olduğu görülmüştür. Belirlenen iki faktörün varyansa yaptıkları toplam katk1 ise \%50.12'dir (Tablo 6). Yapılan analizlerde $\% 40$ ile $\% 60$ arasında değişen varyans oranları, sosyal bilimler için yeterli kabul edilmektedir (Scherer, Wiebe, Luther \& Adams, 1988, akt., Tavşanc1l, 2002). Bulunan toplam varyans değerinin yeterli kabul edilen belirtilen aralıkta bulunması nedeniyle faktör yapısı güçlü bir ölçek oluştuğu söylenebilir.

\section{b)Doğrulayıc1 Faktör Analizi (DFA)}

Doğrulayıc1 faktör analizi, ölçek için belirlenmiş faktör deseninin doğruluğunu test edebilen istatistiksel bir tekniktir (Çokluk, Şekercioğlu ve Büyüköztürk, 2012; Kliene, 2005). Çalışmada yapılan açımlayıcı faktör analizinin ardından belirlenmiş olan faktör yapıları doğrulayıcı faktör analizine tabi tutulmuştur. Bunun için LISREL 9.1 programından yararlanılmıştır.

Şema 1'de, p değerinin 0.01 düzeyinde manidar olduğu görülmektedir. Ancak, çoğu doğrulayıc1 faktör analizinde örneklemin büyük olması nedeniyle $\mathrm{p}$ değerinin manidar olması normaldir. $\mathrm{Bu}$ manidarlık pek çok çalışmada tolere edilmektedir (Çokluk, Şekercioğlu ve Büyüköztürk, 2012). Modelin uyumunda $\chi^{2} /$ serbestlik derecesi (sd) oranının 2.74 (207.91/76=2.74) olduğu görülmektedir (Şema 1). Büyük örneklemlerde $\chi^{2} /$ sd oranın 3 'ün altında olması "mü̈kemmel” uyuma, 5'in altında olması "orta düreyde” uyuma karşllk gelmektedir (Kline, 2005 ; Sümer, 2000).

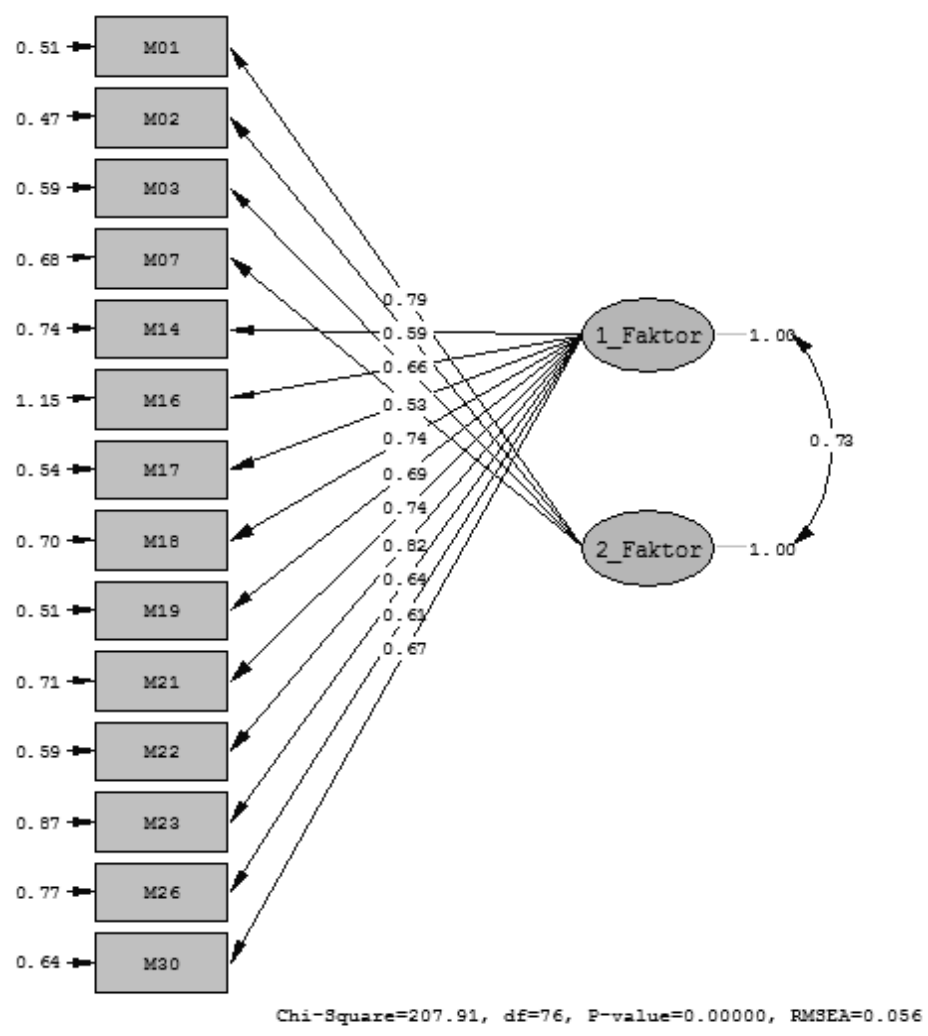

Şema 1. Öğrencilerin Fizik Derslerinde Teknoloji Kullanımına Yönelik Görüş Ölçeği İçin Yol Şemas1 
Erdem, A., \& Uzal, G. (2018). Ölçek geliștirme çalıșması-I: Fizik eğitiminde teknoloji kullanımına yönelik öğrenci görüşleri. Journal of Human Sciences, 15(1), 509-526. doi:10.14687/jhs.v15i1.4504

Yol şemasındaki RMSEA incelendiğinde ise, 0.056 düzeyinde bir uyum indeksinin elde edildiği görülmektedir. RMSEA'nın 0.05 'ten küçük olması "mükemmel” ve 0.08 'den küçük olması “iyi” uyuma işaret ederken (Jöreskog \&Sörbom, 1993), 0.10'dan küçük olması ise "qayrf” uyuma işaret eder (Tabachnick \& Fidel, 2001). Yapılan analiz için elde edilen uyum indeksinin iyi düzeyde olduğu görülmektedir.

Uyum indekslerinin incelenmesine devam edildiğinde, uyum iyiliği indeksi (Goodness of Fit Index, GFI)'nin 0.95 ve düzeltilmiş uyum indeksi (AGFI)'nin 0.93 olduğu görülmektedir. GFI ve AGFI indekslerinin 0.95 'in üzerinde olması "mülkemmel" uyuma, 0.90 'ın üzerinde olması ise "iyi”" uyuma karşılık gelmektedir (Hopper, Caughlan \& Mullen, 2008).Yapılan analiz için GFI ve AGFI'ın iyi bir uyuma sahip olduğu görülmektedir.

Artık ortalamaların karekökü (Root Mean Square Residuals, RMR)'nün 0.05 ve standardize edilmiş artık ortalamaların karekökü (Standardized Root Mean Square Residuals, SRMR) uyum indeksinin 0.04 olduğu görülmektedir. RMR ve SRMR'ın 0.05 'in altında olması "mükeemmel” uyuma, 0.08'in altında olmas1 “iyi”" uyuma (Brown, 2006) ve 0.10'un altında olması ise "zaynf” uyuma karş1lik gelmektedir. Yapılan analiz için RMR ve SRMR'in iyi bir uyuma sahip olduğu söylenebilir. Yaklaş1k hataların ortalama karekökü (Root Mean Square Error of Approximation, RMSEA) indeksinin 0.056 olduğu görülmektedir. RMSEA'nın 0.05 altında olması "mükeemmel" uyuma (Brown, 2006; Jöreskog \&Sörbom, 1993; Raykov \&Marcoulides, 2008; Schumacker \& Lomax, 1996; Sümer, 2000), 0.08’e kadar olmas1 "iyi”" bir uyuma (Hopper, Coughlan \& Mullen, 2008; Jöreskog \& Sörbom, 1993; Sümer, 2000) ve 0.10'un altında olması ise "zayyf" uyuma karşllk gelmektedir (Kelloway, 1989; Tabachnick \& Fidell, 2001). Yapılan analiz için RMSEA'nın iyi bir uyuma sahip olduğu söylenebilir.

Son olarak normlaştırilmamıs uyum indeksi (Non-Normed Fit Index, NNFI) ve karşılaştırmalı uyum indeksi (Comparative Fit Index, CFI) incelendiğinde, NNFI'in 0.98 ve CFI'ın 0.98 olduğu görülmektedir. NNFI ve CFI indekslerinin 0.95 'in üzerinde olması "mükemmel" uyuma, 0.90'in üzerinde olması ise "iyi”" uyuma karşılık gelmektedir (Sümer, 2000). Yapılan analiz için NNFI'ın ve CFI'n mükemmel bir uyuma sahip olduğu görülmektedir. Ölçeğin uyum indeks değerleri Tablo 8'de özet olarak verilmiştir.

Tablo 8. Teknoloji Kullanımı Ölçeğinin Uyum İndeksi değerleri

\begin{tabular}{|c|c|c|}
\hline İndeksler & $\begin{array}{l}\text { Model } \\
\text { Değerleri }\end{array}$ & Ölçütler \\
\hline$\chi^{2}$ & 207.91 & - \\
\hline$\chi^{2} / \mathrm{sd}$ & 2.74 & $\begin{array}{l}\text { <3 mükemmel uyum (büyük örneklemde) (Kline, 2005; Sümer, } \\
2000 \text { ) }\end{array}$ \\
\hline RMSEA & 0.06 & $\leq \mathbf{0 . 0 8}$ iyi uyum (Kelloway, 1989; Tabachnick \& Fidell, 2001) \\
\hline GFI & 0.95 & $\geq 0.90$ iyi uyum (Hopper,Caughlan\&Mullen,2008) \\
\hline AGFI & 0.93 & $\geq 0.90$ iyi uyum (Hopper,Caughlan\&Mullen,2008) \\
\hline SRMR & 0.04 & $\leq 0.05$ mükemmel uyum $\quad($ Brown, 2006) \\
\hline CFI & 0.98 & 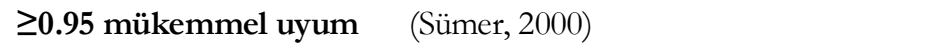 \\
\hline NFI & 0.97 & 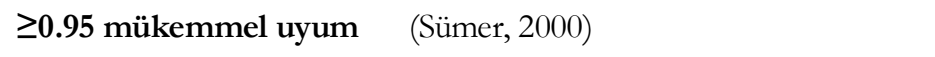 \\
\hline NNFI & 0.98 & $\geq 0.95$ mükemmel uyum $\quad$ (Sümer, 2000) \\
\hline
\end{tabular}

Modifikasyon önerileri (The Modification Indices Suggest to Add an Error Covariance) incelendiğinde, sekiz modifikasyon önerisinin ortaya çıktığı, ancak söz konusu modifikasyonların $\chi^{21}$ ye önemli ölçüde katkı sağlamayacağı görülmüştür. Bu nedenle, modifikasyon yapılmamasına 
Erdem, A., \& Uzal, G. (2018). Ölçek geliştirme çalışması-I: Fizik eğitiminde teknoloji kullanımına yönelik öğrenci görüşleri. Journal of Human Sciences, 15(1), 509-526. doi:10.14687/jhs.v15i1.4504

karar verilmiştir. Yapılan doğrulayıcı faktör analizi sonunda elde edilen uyum indeksi değerlerine göre, ölçek maddelerinin iyi bir uyuma sahip oldukları söylenebilir. Sonuç olarak, bu aşamada da doğrulayıcı faktör analizi sonuçlarına göre elde edilen uyum indeksleri de göz önünde bulundurularak, ölçekten herhangi bir madde çıkarılmamıştır.

\section{Güvenirlik Analizi Aşamas1}

Doğrulayıcı faktör analizinden sonra, lise öğrencilerinin ölçeğe verdikleri cevapların iç tutarlılı̆ını ölçmek için Cronbach Alfa katsayıları hesaplanmıştır. Cronbach Alfa katsayısı; a) $0.00 \leq \alpha<0.40$ ise ölçek güvenilir değildir, b) $0.40 \leq \alpha<0.60$ ise ölçek düşük güvenilirliktedir, c) $0.60 \leq \alpha<0.80$ ise ölçek oldukça güvenilirdir, d) $0.80 \leq \alpha<1.00$ ise ölçek yüksek derecede güvenilirdir (Özdamar, 1999).

Cronbach Alfa katsayısı; "Teknolojinin Önemi, İlgi ve Öğrenme Ortamına Katkısı” faktörü için 0.86 ve "Teknolojinin Öğrenmeye ve Bilgiye Erişime Katkısı" faktörü için ise 0.78 olarak hesaplanmıştır. Tüm ölçeğin güvenirlik katsayısı ise 0.89 olarak bulunmuştur.

Maddelerin madde-toplam korelasyonları; "Teknolojinin Önemi, İlgi ve Öğrenme Ortamına Katkısı" faktörü için 0.47 ile 0.68, "Teknolojinin Öğrenmeye ve Bilgiye Erişime Katkısı" faktörü için ise 0.48 ile 0.65 arasında değişmektedir.

Elde edilen bulgular sonucunda ölçme aracının güvenilir ve geçerli olduğu görülmektedir.

\section{Sonuç ve Öneriler}

$\mathrm{Bu}$ araştırmada, lise öğrencilerinin fizik derslerinde teknoloji kullanımına yönelik görüşlerini belirlemek amacıyla geçerli ve güvenilir bir ölçme aracının geliştirilmesi amaçlanmıştır. Çalışma kapsamında 14 maddeden oluşan Teknolojinin Fizik Eğitiminde Kullanımına Yönelik Öğrenci Görüş Ölçeği üzerinde faktör analizi yapılmış olup, ölçeğin geçerliğine ilişkin bilgi elde edebilmek için döndürülmüş temel bileşenler analizi yapılmıştır. Yapılan faktör analizine göre ölçeğin açıklamış olduğu varyans, toplam varyansın \%50.12'sini oluşturmaktadır. Bu analiz sonucunda iki alt bileşen altında toplanmış olan ölçek maddeleri 14'e indirilmiştir. Faktör analizine göre 1.Faktör, "Teknolojinin Önemi, İlgi ve Öğrenme Ortamına Katkısı", 2. Faktör ise "Teknolojinin Öğrenmeye ve Bilgiye Erişime Katkısı" başlığı altında toplanmıştır. Sonuç olarak geliştirilen ölçek, 1.faktör altında 10, 2.faktör altında ise dört olmak üzere toplam 14 maddeden oluşmaktadır. Analizler sonucunda kalan 14 maddenin açımlayıcı factor analizi sonucu faktör yükleri 0.482 ile 0.820 aralığında değişmektedir. Doğrulayıc1 factor analizi, Teknolojinin Fizik Eğitiminde Kullanımına Yönelik Öğrenci Görüş Ölçeğinin açımlayıcı faktör analizi sonucu elde edilen yapısına uygulanmıştır. Doğrulayıcı faktör analizi sonunda uyum indeksleri GFI=0.95, AGFI=0.93, $\mathrm{NFI}=0.97, \mathrm{NNFI}=0.98, \mathrm{CFI}=0.98, \mathrm{RMSEA}=0.06$ olarak hesaplanmıştır. Bu değerlere göre, ölçek maddelerinin iyi bir uyuma sahip olup model uyumu için de yeterli düzeyde olduğu görülmektedir. Ölçeğin iç tutarlllığını saptamak için hesaplanan Cronbach Alpha katsayıları; birinci alt boyut için 0.86, ikinci alt boyut için 0.78 ve tüm ölçek için 0.89 olarak bulunmuştur. Bu çalışma sonucunda, geçerlik ve güvenilirliği kanıtlanmış olan, lise öğrencilerinin teknolojinin fizik eğitiminde kullanımına yönelik görüşleri ölçeğinin, lise öğrencilerinin kullanımına uygun olduğu görülmektedir.

Araştırma bulguları, teknoloji ürünlerinin farklı derslerin eğitiminde kullanımına yönelik geliştirilecek görüş ölçeklerinin oluşturulmasına yön verebilir. Son y1llarda Milli Eğitim Bakanlığ1 tarafindan liselere Mobil Bilim Laboratuvarı, Tablet PC, etkileşimli tahta vb. teknik donanımlar sağlanmış olup, bunların etkin kullanılması gerekir. Bu nedenle geliştirilen ölçeğin, öğrencilerin teknoloji ürünlerini fizik eğitiminde ne kadar etkin bir şekilde kullandıklarına yönelik görüşlerini belirlemek için yararlı olacağı sonucuna varılmıştır. Ölçek geliştirilirken madde havuzunda bulunan ve içinde Fizik sözcügünü barındıran maddeler analizler sonucunda ölçekten çıkarıldığı için, geliştirilmiş ölçek Fen bilimleri eğitiminde kullanılabilir. 
Erdem, A., \& Uzal, G. (2018). Ölçek geliştirme çalışması-I: Fizik eğitiminde teknoloji kullanımına yönelik öğrenci görüşleri. Journal of Human Sciences, 15(1), 509-526. doi:10.14687/jhs.v15i1.4504

\section{Teşekkür}

Makalemizi gözden geçirerek katkıda bulunan sayın Prof. Dr. Yaşar ERSOY’a ve Araş. Gör.

Dr. Mehpare Saka’ya teşekkürlerimizi sunarız.

\section{Kaynaklar}

Aydın, F. ve Kara, F.N. (2013).Öğretmen adaylarının teknolojiye yönelik tutumları: Ölçek geliştirme çalş̧mass. Türk Fen Eğitimi Dergisi, 10(4), 103-118.

Balc1, B. ve Eşme, İ.(2001).Teknoloji Eğitimi, Yeni Binynlın Başında Fen Bilimleri Eğtitimi Semposynmu,7-8 Eylül, Maltepe Üniversitesi, İstanbul, 214-220.

Bindak, R. (2004). Geometri Tutum Ölçę̆ Güvenirlike Geçerlik Calıșması ve Bir Uygulama. Yayınlanmamıs doktora tezi, Dicle Üniversitesi, Diyarbakır.

Boser, A. R., Palmer, J. D. \&Daugherty, M. K.(1998). Students Attitudes Toward Technology in Selected Technology Education Programs. Journal of Technology Education 10(1), 4-19.

Bozkurt, E. veSarlkoç, A. (2008).Fizik eğitiminde sanal laboratuar, geleneksel laboratuarın yerini tutabilir mi? Selcuk Üniversitesi Abmet Kelesoğh Eğitim Fakïltesi Dergisi, 25, 89-100. http://dx.doi.org/10.1016/j.sbspro.2010.03.735, adresinden 13.01.2014 tarihinde indirilmiştir.

Brown, T., A. (2006).Confirmatory Factor Analysis for Applied Research.(First Edition). NY: Guilford Publications, Inc.

Büyüköztürk, Ş. (2012). Sosyal Bilimler için Veri Analiæi El Kitabı: İstatistik Araștırma Deseni, SPSS Uygulamalar ve Yorum (16. Baskı). Ankara: PEGEM A Yayıncilık.

Clement, J. (1982). Student's Preconceptions in Introductory Mechanics. American Journal of Physics, 50(1), 6671.

Çepni, S. (2005). Arasttrma ve Proje Calısmalarna Giriş (2. Basım).Trabzon: ÜçyolYayıncılık.

Çokluk, Ö., Şekercioğlu, G. ve Büyüköztürk, Ş. (2012). Sosyal Bilimler için Çok Değģ̆kenli İstatistik SPSS ve LISREL Uygulamalar (2. basim). Ankara: PEGEM A Yayıncilik.

EARGED (2005).PISA 2003 Projesi Ulusal Nibai Raporu, Ankara: EARGED Yay.

EARGED (2007).PIS A 2006 Uluslararası Ögrrenci Değerlendirme Programı Ulusal Ön Rapor, Ankara: EARGED Yay.

Edmunds, R., Thorpe, M. \& Conole, G. (2012). Student attitudes towards and use of ICT in course study, work and social activity: A technology acceptance model approach. British Journal of Educational Technology, 43(1), 71-84.

Francis, L. J. ve Evans, T. E. (1995). The reliability and validity of the Bath County computer attitude scale. Journal of Educational Computing Research, 12(2), 135-146.

Halloun, I. A. \& Hestenes, D. (1985). The initial knowledge state of college physics students. American Journal of Physics, 53(11), 1043-1055.

Harwood, W. S. \& McMahon, M. M. (1997). Effects of integrated video media on student achievement and attitudes in high school chemistry. Journal of Research in Science Teaching, 34(6), 617-631.

Hestenes, D. \& Halloun, I.A.(1987). Modeling instruction in mechanics. American. J. Phys., 55, 455-462.

Heuvelen, A.V.(1991). Learning to think like aphysicist: A review of research-based instructional strategies. American J. Phys. 59(10), 891-897.

Hopper, D., Coughlan, J. \& Mullen, M. (2008). Structural equation modelling: Guidelines for determining model fit. The Electronic Journal of Business Research Methods. 6(1), 53-60.

Inoue,Y. (2007).University Students' Perceptions of Computer Technology Experiences. Paper presented at the AERA Annual Meeting (pp. 2-13), April 9-13, 2007, Chicago.

Jöreskog, K. G. \& Sörbom, D. (1993). Lisrel 8: Structural Equation Modeling with The Simplis Command Language. Lincolnwood: Scientific Software International, Inc.

Kalayc1, Ş. (Ed.). (2005).SPSS Uygulamalı Çok Değģ̧kenli Istatistik Teknikleri. Ankara: Asil Yayın Dağıım.

Kelloway, K., E. (1989). Using Lisrel for Structural Equation Modeling: A Researcher's Guide. London: Sage.

Kıyıcı, G. ve Yumuşak, A. (2005). Fen bilgisi laboratuarı dersinde bilgisayar destekli etkinliklerin öğrenci kazanımlanı üzerine etkisi; asit-baz kavramlanı ve titrasyon konusu örneği. The Turkish Online Journal of Educational Technology, 4(4), 130-134. 
Erdem, A., \& Uzal, G. (2018). Ölçek geliştirme çalışması-I: Fizik eğitiminde teknoloji kullanımına yönelik öğrenci görüşleri. Journal of Human Sciences, 15(1), 509-526. doi:10.14687/jhs.v15i1.4504

Kızılcık, H., Temiz, B. K., Tan, M. ve İngeç, Ş. K. (2007). Sözel bölüm öğretmen adaylanının fen bilimlerine, fen eğitimine ve teknolojiye karşı tutumlarının araştırılması. Eğitim ve Bilim, 32(146), 80-88.

24.02.2016'dehttp://egitimvebilim.ted.org.tr/index.php/EB/article/view/750/148 adresinden indirilmiștir.

Kliene, R. B. (2005).Principles and Practice of Structural Equation Modeling (2nd ed.). NY: Guilford Publications, Inc.

Koç, A. ve Böyük, U. (2013). Fen ve teknoloji eğitiminde teknoloji tabanlı öğrenme: Robotik uygulamaları. Türk Fen Eğitimi Dergisi, 10(1), 139-155.

Kolçak, D., Y., Moğol, S. ve Ünsal, Y. (2014). Fizik öğretiminde kavram yanılgılarının giderilmesine ilişkin laboratuvar yöntemi ile bilgisayar simülasyonlanının etkilerinin karşılaşturılması. Eğitim ve Bilim, 39(175), 154-171.

Li, Q. (2007). Student and Teacher Views About Technology: A Tale of Two Cities? Journal of Research on Technology in Education, 39(4), 377-397.

McDermott, L. C. \& Redish, E. F. (1999). Resource Letter on Physics Education Research. American J.Phys., 67, 755-767.

Nuhoğlu, H. (2008). İlköğretim fen ve teknoloji dersine yönelik bir tutum ölçeğinin geliştirilmesi. Ilkogretim Online, 7(3), 627-639. 27.02.2016 tarihinde [Online]: http://ilkogretim-online.org.tr.adresinden indirilmiştir.

OECD (2005).Performance Information in the Budget Process: Results of the OECD 2005 Questionnaire.

Ornek, F., Robinson R. W. \& Haugan, P. M. (2008). What makes physics difficult? International Journal of Environmental and Science Education, 3(1), 30-34.

Öğüt, H., Altun, A. A., Sulak, S. A. ve Koçer, H. E. (2004). Bilgisayar destekli, internet erişimli interaktif eğitim cd'si ile e-eğitim. TheTurkish Online Journal of EducationalTechnology, 3(1), 67-74.

Öksüz, C. Ak, Ş. ve Uça, S. (2009). İlköğretim Matematik Öğretiminde Teknoloji Kullanımına İlişkin Alg1 Ölçeği.Yüzüncü Yıl Üniversitesi Eğitim Fakültesi Dergisi, 6(1), 270-287. Web: http:/ /efdergi.yyu.edu.tr/

Özarslan, M., Çetin, G. ve Sarıtaş, T. (2013). Biyoloji, Fizik ve Kimya Öğretmen Adaylarının Bilgi ve İletişim Teknolojilerine Yönelik Tutumları. Türk Fen Ë̆itimi Dergisi, 10(2), 85-100.

Özdamar, K. (1999). Paket Programlar ile İstatistiksel Veri Analizi I (2. Basim). Eskişehir: Kaan Kitabevi.

Özdener, N. (2002). Deneysel öğretim yöntemlerinde benzetişim (simulation) kullanımı. TheTurkish Online Journal of Educational Technology, 4 (4), 93-98.

Prinsen, F., Vloman, M. L. L. \& Terwel, J. (2007). The influence of learner characteristics on degree and type of participation in a CSCL environment. British Journal of Educational Technology, 38(6), 1037-1055.

Ramsden, E., (2002). An Introduction to Computer Simulation and Modeling. http://www.sensorsmag.com/articles/0602/life/ (June 2007).

Raykov, T. \& Marcoulides, G. A. (2008).An Introduction to Applied Multivariate Analysis (First Edition). NY: Taylor and Francis Group.

Redish, E. F. (1994). Implications of cognitive studies for teaching physics. American Journal of Physics, 62(9), 796-803.

Rugayah, H., Hashim, H. \& Wan, N. M. (2004). Attitudes toward learning about and working with computers of students at unit. The Turkish Online Journal of Educational Technology, 3(2), 24-35.

Schumacker, R. E. \& Lomax, R. G. (1996). A Beginner's Guide to Structural Equation Modeling. (First Edition). NJ: Lawrence Erlbaum Associates, Inc.

Sümer, N. (2000). Yapısal eşitlik modelleri. Türk Psikoloji Yą̣lar, 3(6), 49-74.

Sünkür, M., Arabacı,B. ve Şanl1; Ö. (2012). Akıllı tahta uygulamaları konusunda İlköğretim 2. Kademe ögrencilerinin görüşleri (Malatya ili örneği). e-Journal of New World Sciences Academy. 7(1), 313-321.

Şencan, H. (2005). Sosyal ve Davranıssal Ölçümlerde Güvenirlike ve Geçerlilik. (1.basım). Ankara: Seçkin Yayınlanı.

Şengel, E., Özden, M. Y. ve Geban, Ö. (2002). Bilgisayar Simülasyonlu Deneylerin Lise Öğrencilerinin Yerdeğiştirme ve Hız Kavramlannı Anlamadaki Etkisi. V. Ulusal Fen Bilimleri ve Matematik Eğgitimi Kongresi, 2, 1424-1429.

Tabachnick, B. G. \& Fidel, L. S. (2001). Using Multivariate Statistics. (Fourth Edition). MA: Allyn and Bacon, Inc.

Tataroğlu B. ve Erduran A., (2010). Matematik dersinde ak1llı tahtaya yönelik tutum ölçeğinin geliştirilmesi. Turkish Journal of Computer and Mathematics Education. 1(3), 233-250. http://www.bilmat.ktu.edu.tr/bilmat/index.php/deneme1/article/view/18/1 
Erdem, A., \& Uzal, G. (2018). Ölçek geliştirme çalışması-I: Fizik eğitiminde teknoloji kullanımına yönelik öğrenci görüşleri. Journal of Human Sciences, 15(1), 509-526. doi:10.14687/jhs.v15i1.4504

Tavşancıl, E. (2002). Tutumlarn ölçülmesi ve SPSS ile veri analiz̨i. Ankara: Nobel Yayıncıllk

Tavşancıl, E. (2005). Tutumlarn Ölçülmesi ve SPSS ile Veri Analiri.(2.basım). Ankara: Nobel Yayınları. No 399.

Tubaishat, A. (2014). An investigation in to the attitudes of nursing students toward technology. Journal of Nursing Research. 22(2),119-125.

Türel, Y. K. (2011). An interactive whiteboard evaluation survey university students: Validity and reliability analyses. Education Sciences, 6(2), 1894-1903.

UNESCO.(2014). Information and Communication Technology (ICT) in Education Asia. 11.03.2016 tarihinde (http://www.uis.unesco.org/Communication/Documents/ICT-asia-en.pdf) adresinden indirilmiştir.

Yang, K. Y. \& Heh, J. S. (2007). The impact of internet virtual physics laboratory instruction on the achievement in physics, science process skills and computer attitudes of 10th grade students. $J$. Science EducTechnol, 16, 451-461.

Yavuz, S. (2005).Developing a technologyattitudescaleforpre-service chemistryteachers.TheTurkish Online Journal of Educational Technology, 4(1), 17-25.

Yurdugül, H. (2005). Ölçek geliştirme çalışmalarında kapsam geçerliliği için kapsam geçerlilik indekslerinin kullanım. IV.Ulusal Eğitim Bilimleri Kongresi, 28-30 Eylül, Denizli.

Yurdugül, H. ve Aşkar, P. (2008). An investigation of the factorial structures of pupils' attitude towards technology (PATT): A Turkish sample. Elementary Education Online, 7(2), 288-309. 27.02.2016 tarihinde [Online]: http://ilkogretim-online.org.tr adresinden indirilmiştir.

\section{Ek-1}

\section{Extended English Summary}

Firstly, students should have positive opinions for use of technology in physics lessons to learn more qualified physics by using technology productively. Ministry of National Education has furnished high schools with technical equipmentsuch as Mobile Science Labs, Tablet PCs and interactive boards and it is necessary to use thisequipment effectively. Thus, knowing the opinions of students for use of technology in physics lessons is gaining importance to structure the physics lessons in terms of productivity. Determining high school students' opinions for use of technology in physics education sets ground for our research.

One of the conditions to be successful in physics teaching at our schools is to enable students to structure physics knowledge rapidlyby realizing conceptual learning with the support of technology. Hence, it is necessary to determine students' opinions for use of technology in physics education. The aim of this study is to develop a scale to determine the high school students' opinions for use of technology in physics lessons.

\section{Method}

The scale of high school students' opinions for use of technology in physics lessons was prepared by going through these phases:

Related literature was scanned by the researchers and scales used in other studies were examined.Draft opinion items were written asking students' opinions for trial purpose in the light of aforementioned examinations. Then, six experts in this field were consulted about the length, understand ability and effectivity of the chosen items. For content validity, 31 expressions of students about use of technology in physics teaching were gathered in a pool and presented to experts via a form. Taking in to consideration of suggestions and feedback, item pool was restructured.

13 items were removed from the form that was statistically in significant on account of Content Validity Ratio (CVR) obtained for each item. Content Validity Criterion(CVC) of candidate scale form was 0.99 for the opinions of six experts(Yurdugül, 2005). Content Validity Index (CVI) was found as 1.00 by calculating the average CVRs of items left in the form. As CVI $>=$ CVC, the content validity of scale was statistically significant.

Content validity provided by experts, 18-item 5 Likert type candidate form was prepared. There were seven questions about the demographic information of students in the candidate form.

A candidate form was designed to be used in the proposed study, then, in order to develop and improve the form, a pilot study was conducted. Students' Opinions For Use Of Technology In Physics Education Scale(SOFUOTIPES) consisted of 18-items that reflected the opinions of high school students 
Erdem, A., \& Uzal, G. (2018). Ölçek geliștirme çalıșması-I: Fizik eğitiminde teknoloji kullanımına yönelik öğrenci görüşleri. Journal of Human Sciences, 15(1), 509-526. doi:10.14687/jhs.v15i1.4504

for use of technology in physics lessons. The lowest score that might be taken from measurement tool was 18, the highest score was 90 . The study group consisted of 562 students who studying at $9^{\text {th }}, 10^{\text {th }}, 11^{\text {th }}$ and $12^{\text {th }}$ grades of nine different high schools as Ebru Nayim Science High School, Aka College Science High School, Tekirdağ Anatolian High School, Tekirda ̆ Municipality Anatolian Teacher Training High School, Namık Kemal High School, Fatih Anatolian High School, Aka College Science and Anatolian High School and Tuğlacilar Anatolian High School located in Tekirdağ city, Süleymanpaşa district in 20132014 academic year.

\section{Results}

For the data analysis obtained in the study, first item analysis that was carried out in two-stage and then factor analysis (exploratory and confirmatory factor analyses) was conducted.

The average differentiation of sub-super groups and correlation-based item analysis was conducted in this study. As the result of average differentiation- based item analysis of sub-super group, any of items were removed from the scale. Aiming at determining which items among 18 items were working, distinctiveness of each item, in other words, item-total correlation was examined. During the analysis, first M09 then M12 items were removed from the scale since item total correlations were below than 0.40. Apart from the removed items, item-total correlations of all items ranged between $0.490-0.672$ and their $t$ values were significant (Table 3). Thus, it can be said that the scale has very good items.

Exploratory and confirmatory factor analyses were conducted to determine construct validity.

As the result of exploratory factor analysis, contribution of factors to total variance was signified as $40.82 \%$ for factor a) "Importance of Technology, Its Contribution to Interest and Learning Environment" and $9.30 \%$ for factor b) "Contribution of Technology to Learning and Accessing the Information". Contribution to total variance of these two factors was $50.12 \%$ (Table 7). Analysis on social sciences shows that the variance rates between $40 \%$ and $60 \%$ are accepted as sufficient (qtd. in Tavşancil, 2002; Scherer, Wiebe, Luther \& Adams, 1988).

We can say that the scale has a strong factor structure because of total variance value is within the specified range. Of the 14 items in the scale, after varimax-rotated application, the first factor of scale was determined to be made of 10 items, and the second factor was determined to be made of four items. Load values of the factors from the items in the first factor ranged from 0.482 to 0.714 . The same values were between 0.583 and 0.820 for the four items in the second factor.

When RMSEA (Root Mean Square Error of Approximation) of the scheme was examined as a result of confirmatory factor analysis, it was seen that a fit index as 0.056 was obtained. It was seen that the fit index obtained for the analysis was at good level. When the fit indices were continued to be examined, it was seen that Goodness of Fit Index (GFI) was 0.95 and the Adjusted Goodness of Fit Index (AGFI) was 0.93. For the conducted analysis, GFI and AGFI seemed to have a good fit. Finally, when the Non-Normed Fit Index (NNFI) and the Comparative Fit Index (CFI) were examined, it was seen that NNFI was found as 0.98 and CFI was found as 0.98. For the analysis, NNFI and CFI seemed to have $a$ perfect fit.

When Modification Indices Suggested to Add an Error Covariance were examined, it was seen that eight modification proposals were brought forward; however, it was seen that the relevant modifications would not provide a significant contribution to $\chi^{2}$ Chi-Square Goodness of Fit. For this reason, it was decided not to make any modifications. According to the fit index values obtained as a result of the confirmatory factor analysis, it can be said that the scale items had a good fit. As a result, no items were removed from the scale, considering the obtained fit indices according to the confirmatory factor analysis results.

Cronbach Alpha coefficient was calculated as 0.86 for the "The Importance of Technology, Its Contribution to Interest and Learning Environment" factor and 0.78 for the "Contribution of Technology to Learning and Accessing the Information" factor. The reliability coefficient of the whole scale was found as 0.89 . Item-total correlations of the items ranged from 0.47 to 0.68 for the "The Importance of Technology, Its Contribution to Interest and Learning Environment" factor and between 0.48 and 0.65 for the "Contribution of Technology to Learning and Accessing the Information"factor.

\section{Discussion}

In this research, it was aimed to develop a valid and reliable measurement tool to determine the opinions of high school students for the use of technology in physics lessons. In the scope of the study, 
Erdem, A., \& Uzal, G. (2018). Ölçek geliştirme çalışması-I: Fizik eğitiminde teknoloji kullanımına yönelik öğrenci görüssleri. Journal of Human Sciences, 15(1), 509-526. doi:10.14687/jhs.v15i1.4504

factor analysis was conducted on the Students' Opinions For Use Of Technology In Physics Education Scale, which consisted of 14 items. Obtaining information about the validity of the scale, varimax-rotated principal components analysis was conducted.

According to the factor analysis, the variance which the scale was explained, comprised $50.12 \%$ of the total variance. As a result of this analysis, the scale items collected under the two subcomponents were reduced to 14. According to the factor analysis, Factor 1 was gathered under the heading of "The Importance of Technology, Its Contribution to Interest and Learning Environment" and Factor 2 under the heading "Contribution of Technology to Learning and Accessing the Information". As a result, the developed scale consisted of a total of 14 items, 10 items under the 1 .factor and 4 items under the 2 . factor. The results of exploratory factor analysis for the remaining 14 substances varied from 0,482 to 0,820. Explanatory factor analysis of the Students' Opinions For Use Of Technology In Physics Education Scale was applied to the resulting structure. As the result of the confirmatory factor analysis, the fit indices were calculated as GFI $=0.95, \mathrm{AGFI}=0.93, \mathrm{NFI}=0.97, \mathrm{NNFI}=0.98, \mathrm{CFI}=0.98, \mathrm{RMSEA}=0.06$. In the light of these values, the scale indicates that it has a good fit and that it is sufficient for model fit.

The findings of the research can shed light on the formation of scale of opinions for the use of technology products in the education of different subjects. In recent years, the Ministry of National Education has furnished high schools with technical equipment such as Mobile Science Labs, Tablet PCs and interactive boards and it is necessary to use this equipment effectively. Therefore, it is suggested that the developed scale would be useful for determining the students' opinion about how effectively they use technology products in physics education.

\section{Conclusion}

As a result of this study, it is seen that the scale of opinions on the use of technology in the physics education of high school students, whose validity and reliability were proven, is suitable for the use of high school students. As the scale is being developed, the materials that contain the word of Physics in it are extracted from the scale in the pool of materials, as a result of the analysis, it is suggested that this scale can be used in Science education.

Ek-2

Teknolojinin Fizik Eğitiminde Kullanımına Yönelik Öğrenci Görüş Ölçeği

\begin{tabular}{|c|c|c|c|c|c|c|}
\hline M.No & Öğrencilerin Görüşleti & 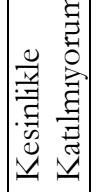 & 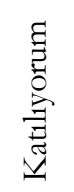 & 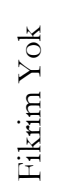 & 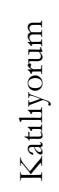 & 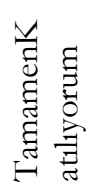 \\
\hline & \multicolumn{6}{|l|}{ Teknolojinin Önemi, İlgi ve Öğrenme Ortamına Katkısı } \\
\hline M14 & Laboratuarda yapılamayan deneylerin anlaşılmasına katkısı olur & (1) & (2) & (3) & (4) & (5) \\
\hline M16 & Teknoloji kullanımı öğrenme ortamını zenginleştirir & (1) & (2) & (3) & (4) & (5) \\
\hline M17 & Teknoloji kullanımı hayal gücümü geliştirir & (1) & (2) & (3) & (4) & (5) \\
\hline M18 & Yaratıcı düşünme becerilerimi geliştirmede yardımcıdır & (1) & (2) & (3) & (4) & (5) \\
\hline M19 & Konuları öğrenmede ilgimi arttırır & (1) & (2) & (3) & (4) & (5) \\
\hline M21 & Öğrenmeye daha çok güdüler (isteklendirir) & (1) & (2) & (3) & (4) & (5) \\
\hline M22 & Teknoloji kullanımı takım çalışması becerilerimi geliştirir & (1) & (2) & (3) & (4) & (5) \\
\hline M23 & Bilimsel düşünme becerilerimi geliştirmeme katkısı olur & (1) & (2) & (3) & (4) & (5) \\
\hline M26 & Öğrenme etkinliklerine katılım olanaklarını arttırır & (1) & (2) & (3) & (4) & (5) \\
\hline \multirow[t]{2}{*}{ M30 } & Teknolojinin derslerde daha sık kullanılmasını isterim & (1) & (2) & (3) & (4) & (5) \\
\hline & \multicolumn{6}{|l|}{ Teknolojinin Öğrenmeye ve Bilgiye Erişime Katkıs1 } \\
\hline M01 & Konu içeriğini kolaylıkla anlamama yardımcı olur & (1) & (2) & (3) & (4) & (5) \\
\hline M02 & Konuları kısa sürede öğrenmeme olumlu etkisi vardır & (1) & (2) & (3) & (4) & (5) \\
\hline M03 & Bilgiye hızlı erişmemde çeşitli olanaklar sağlar & (1) & (2) & (3) & (4) & (5) \\
\hline M07 & Birden çok duyu organıma hitap eder & (1) & (2) & (3) & (4) & (5) \\
\hline
\end{tabular}

